\title{
Addendum: Large-scale subduction of continental crust implied by India-Asia mass-balance calculation
}

Miquela Ingalls, David B. Rowley, Brian Currie and Albert S. Colman

Nature Geoscience 9, 848-853 (2016); published online 19 September 2016; addendum published after print 27 March 2017.

The authors omitted to cite a paper ${ }^{5}$ that used a crustal mass-balance approach, but alternative constraints on paleogeography and pre-collisional crustal geometries, to argue that about 40 to $50 \%$ of Indian crust is missing from the present-day crustal reservoir of the Himalayan-Tibetan system and may have been recycled into the mantle. Given limited constraints on the uncertainty of this estimate, the authors chose to focus their comparison on the later work of Yakovlev and Clark (2014). Nevertheless, the authors have decided the work of Replumaz and colleagues merits citation.

\section{References}

5. Replumaz, A., Negredo, A.M., Guillot, S., van der Beek, P. \& Villaseñor, A. Crustal mass budget and recycling during the India/Asia collision. Tectonophysics 492, 99-107 (2010). 